ANGELIKA MODLIŃSKA-PIEKARZ *- LUBLIN

\title{
INFORMATOR O ZBIORZE RĘKOPISÓW BIBLIOTEKI UNIWERSYTECKIEJ KUL
}

\author{
I. Nazwa i adres instytucji posiadającej rękopisy \\ Biblioteka Uniwersytecka Katolickiego Uniwersytetu Lubelskiego Jana Pawła II \\ 20-023 Lublin, ul. F. Chopina 27, \\ tel. (81) 445-31-12, e-mail: rekopisy@kul.lublin.pl
}

\section{Ilość rękopisów}

Biblioteka Uniwersytecka KUL posiada ok. 10.000 jednostek rękopisów, w tym z XIII wieku - 2; z XIV wieku - 3; z XV wieku - ok. 50; z XVI wieku - ok. 200; z XVII - ok. 400; z XVIII wieku - ok. 2000; z XIX wieku - ok. 3000; z XX wieku - ok. 6000. Z tego materiały archiwalne stanowią ok. 3000 j., spuścizny $7000 \mathrm{j}$. Do chwili obecnej opracowano $6821 \mathrm{j}$.

Udostępnianie: w Czytelni Zbiorów Specjalnych w Gmachu Głównym BU KUL, II piętro; godziny otwarcia: w poniedziałki w godz. 11-16, wtorki - piątki w godz. 10-16, w soboty w godz. 9-15. Katalogi drukowane (cząstkowe) - patrz niżej przy omówieniach poszczególnych części składowych zbioru.

Istnieje pracownia reprograficzna, czynna we wtorki i piątki w godz. 9-15.

\section{Katalogi drukowane, w maszynopisach i rękopiśmienne}

Katalogi podstawowe

1. Inwentarz rękopisów (księga rękopiśmienna, t. 1-2; w maszynopisie, t. 3-12 - obejmuje razem 3540 jednostek;

2. Inwentarz dyplomów (księga rękopiśmienna i w pliku tekstowym) - razem 226 jednostek;

\footnotetext{
*Angelika Modlińska-Piekarz - dr neolatynistyki, adiunkt w Bibliotece Uniwersyteckiej KUL.
} 
3. Katalog dokumentów i listów (w pliku tekstowym), obejmuje te same jednostki, co inwentarz dyplomów

4. Katalog akcesyjny (kartkowy) obejmujący 3055 jednostek.

Uwaga: Do wszystkich opracowanych sygnatur są osobne indeksy zawierające łącznie hasła osobowe, instytucji i miejscowe. Inwentarze, katalogi kartkowe $\mathrm{i}$ indeksy dostępne tylko na miejscu.

Katalogi cząstkowe (drukowane)

1. Katolog dokumentów - Bibliografia: H. Mańkowska, Katalog dokumentów Bibl. Uniwersyteckiej KUL, „Archiwa Biblioteki i Muzea Kościelne” (dalej: ABMK), 17 (1968) s. 5-28 [obejmuje 71 sygnatur]; Nowy katalog dokumentów $i$ listów Biblioteki Uniwersyteckiej KUL, oprac. A. Modlińska-Piekarz, Lublin 2012, ss. $170+$ ilustracje.

2. Archiwum Filomatów - Bibliografia: H. Mańkowska, Rękopisy z «Archiwum Filomatów». Fragment inwentarza zbiorów rękopiśmiennych Biblioteki KUL, ABMK, 26 (1973) s. 59-88; H. Mańkowska, Rękopisy z „Archiwum Filomatów”. Katalog, ABMK, 47 (1983) s. 107-174.

3. Zbiory ks. Bronisława Ussasa - Bibliografia: Zbiór rękopisów ofiarowanych przez ks. B. Ussasa Bibl. Uniwersyteckiej KUL, ABMK, 39 (1979) s. 55-126 [Katalog rękopisów, oprac. H. Mańkowska, s. 63-126].

4. Archiwum Jana Steckiego - Bibliografia: H. Ziółek, Archiwum Jana Steckiego (Katalog rękopisów), ABMK, 57 (1988) s. 331-447.

5. Rękopisy cerkiewnosłowiańskie - Bibliografia: Â. N. Ŝapov, Vostočno-slavânskie i ûžnoslavânskie rukopisnye knigi v sobraniâch Pol'skoj Narodnoj Respubliki, Moskva 1976, t. 2, s. 7-36; A. Naumow, A. Kaszlej, Rękopisy cerkiewnosłowiańskie w Polsce. Katalog. Kraków 2002 [oraz wydanie drugie zmienione 2004].

\section{Opracowania dotyczące archiwum}

Bibliogr.: P. Kremer, Biblioteka Uniwersytetu Lubelskiego „Głos lubelski”, 10 (1923) nr 60, s. 10-11; Biblioteka Uniwersytetu Lubelskiego, „Przegląd Bibliograficzny", 1 (1927) s. 157-158; Biblioteka Główna i Zakłady KUL, w: Sprawozdanie KUL, Lublin 1938, s. 20-21; R. Gustaw, W. Nowodworski, Dwadzieścia lat Biblioteki Uniwersyteckiej KUL (1938-1958), ABMK, 1 (1959) s. 133-160; D. Dzierzkowska, Biblioteka Główna KUL. 1918-1939, ABMK, 8 (1964) s. 187242; H. Mańkowska, Sekcja rękopisów, ABMK, 23 (1971) s. 140-146; Z. Goleman, Sekcja Rękopisów, w: Zbiory specjalne Biblioteki Uniwersyteckiej Katolickiego Uniwersytetu Lubelskiego, red. M. Trojnacka, Lublin 2004, s. 11-15. 


\section{Historia zbioru}

Biblioteka Uniwersytecka KUL od początku swego istnienia (tj. od 1918 roku) gromadziła zbiory rękopiśmienne. Do roku 1949 roku wraz ze wszystkimi zbiorami bibliotecznymi, znajdowały się one w gmachu pobernardyńskim przy ul. Dolnej Panny Marii. W okresie przedwojennym było ich jeszcze niewiele. Według danych statystycznych w 1927 roku Biblioteka posiadała 62 rękopisy, a w 1939 -112. Z pewnością było ich jednak więcej, gdyż same rękopisy pochodzące z daru Jerzego Moszyńskiego liczyły około 100 jednostek, a wiadomo, że były też inne dary osób prywatnych oraz pierwsze spuścizny i fragmentaryczne materiały profesorów KUL, m.in. po rektorze KUL ks. Idzim Radziszewskim, czy ks. dr Cezarym Pęcherskim. W tym czasie rękopisy nie były jeszcze opracowane i nie udostępniano ich. Ze względu na brak pełnych danych akcesyjnych na temat rękopisów nabytych przed wojną, trudno stwierdzić, czy straty wojenne poniesione przez Bibliotekę KUL dotyczą w jakimś stopniu zbiorów rękopisów. Podczas wojny, w latach 1940-1944, gdy Biblioteka KUL została wchłonięta przez Staatsbibliothek, kierowana przez władze niemieckie, rękopisy prawdopodobnie nie zostały uszczuplone. Najcenniejsze rękopisy nabyte przed wojną, czyli te otrzymane od Jerzego Moszyńskiego zachowały się w całości. W latach 1948-1950 z powodu braku wykwalifikowanego personelu opracowaniem rękopisów zajął się osobiście dyrektor Biblioteki, prof. Andrzej Wojtkowski. Do sierpnia 1950 opracował i zapisał w inwentarzu 625 jednostek rękopiśmiennych oraz 68 dyplomów. W tym czasie (w 1949 roku) zbiory rękopiśmienne przeniesiono wraz innymi zbiorami bibliotecznymi do nowego gmachu Biblioteki przy ul. Chopina 27. Kolejny dyrektor Biblioteki, o. dr Romuald Gustaw OFM, tworząc samoistny dział rękopisów, wyłączył rękopisy z ogólnej grupy zbiorów specjalnych, ale dopiero w 1958 roku dział uzyskał własnego pracownika (od 2000 roku na etacie w Sekcji Rękopisów stale zatrudnione są dwie osoby). Od 1958 roku datuje się zatem systematyczne opracowanie zbiorów, które od 1944 znacznie się powiększyły. Już w pierwszych latach po wojnie, tj. 1946-1949 Bibliotekę KUL wzbogaciła znaczna i do dziś dokładnie nieustalona liczba rękopisów ze Zbiornicy Księgozbiorów Zabezpieczonych, które nieodpłatnie przyznało Bibliotece KUL Ministerstwo Oświaty jako rekompensatę za poniesione straty wojenne. Zbiory te pochodziły z magazynów znajdujących się w Bytomiu, Katowicach, Gliwicach i Wrocławiu. Sprowadzał je stamtąd o. dr Romuald Gustaw OFM w latach 19461953 wyszukując dzieła odpowiednie do profilu naukowego Uniwersytetu i Biblioteki, przedstawiające wartość naukową i historyczną, są to między innymi liczne źródła historyczne i teologiczne z XV-XVIII wieku, zbiory Georga Wilhelma von Raumera dotyczące Brandenburgii i Prus od XV do XIX wieku, a także liczne Silesiaca od XVII od XVIII wieku. W pierwszych latach po wojnie trafiły do biblioteki także rękopisy z Biblioteki Kapituły Greckokatolickiej w Przemyślu przekazane wraz z księgozbiorem w 1946 roku. Są to przeważnie cerkiewnosłowiańskie księgi liturgiczne z XVI-XVIII wieku oraz polskie i łacińskie rękopisy teologiczne z XVI-XIX wieku W latach pięćdziesiątych pojawiły się też pierwsze 
spuścizny po profesorach: Henryku Jakubanisie, Mieczysławie Popławskim, Leonie Białkowskim, Zygmuncie Kukulskim, doktorze Witoldzie Nowodworskim oraz pojedyncze dary osób prywatnych. W latach 1946-1976 można mówić o planowym gromadzeniu zbiorów rękopiśmiennych. Dyrektor o. Romuald Gustaw dokonał zakupu kilku ważnych kolekcji, a także cennych kodeksów i dokumentów, ważnych dla historii Polski i Kościoła. Znaczna część rękopisów wpływała jednak w sposób przypadkowy, jako dary osób prywatnych, należy jednak pamiętać, iż cały zbiór rękopiśmienny został ukształtowany w pewien sposób przez ówczesną sytuację polityczną i społeczną. Katolicki Uniwersytet Lubelski w czasach PRL był jedną z nielicznych instytucji, której zaufało środowisko katolickie i antykomunistyczne, dlatego nie wahano się składać tu różnych materiałów i opracowań, które przez ówczesną władzę były zakazane, np. dotyczących walki zbrojnej AK, walki z komunizmem, polskiej emigracji, dowodów represji Polaków wyznania katolickiego w Polsce i ZSRR, literatury katolickiej. Ponadto gromadzono też spuścizny naukowe po zmarłych profesorach KUL: Aleksandrze Kossowskim, Stefanie Kawynie, Ludomirze Bieńkowskim, Czesławie Zgorzelskim, biskupie Czesławie Sokołowskim i wielu innych, a także profesorów innych uczelni: m. in. materiały po profesorze Stanisławie Kocie, Władysławie Tatarkiewiczu. Biblioteka otrzymała też w darze materiały literackie, m.in.: Adama Mickiewicza, Jerzego Lieberta, Józefa Kapuścińskiego, Jerzego Szaniawskiego, Zygmunta Ławrynowicza, Antoniego Gołubiewa, Edy Ostrowskiej, Matyldy Wełny.

\section{Charakterystyka zbioru}

a) Większe kolekcje:

Zbiory Haliny Doria-Dernalowicz (1896-?). Dokumenty osobiste, wspomnienia, materiały do działalności własnej, materiały związane z życiem i działalnością Marii Kleniewskiej, materiały dot. Bractwa Pielgrzymstwa Polskiego, Stowarzyszenia Zjednoczonych Ziemianek, Koła Młodych Ziemianek oraz innych organizacji i stowarzyszeń katolickich w Polsce i na świecie, korespondencja (21 j.). Bibliogr.: M. Kleniewska, Wspomnienia, red. i oprac. W. Włodarczyk, Wilków 2002.

Zbiory Zygmunta KLUKowskiego (1885-1959) lekarza, bibliofila, historyka, działacza społecznego, zakupione w 1950 roku, dokumenty osobiste, materiały do działalności bibliofilskiej, lekarskiej i społecznej Z. Klukowskiego, prace naukowe, a ponadto fragmenty akt oddziałów partyzanckich AK na Zamojszczyźnie, materiały do dziejów Zamojszczyzny, dzienniki, korespondencja (62 j.). Bibliogr.: B. Królikowski, Klukowski-zbieracz, wydawca i autor pamiętników, „Pani. pol.”, 2 (1972) nr 3, s.28-39; Z. Klukowski, Dzienniki, Lublin 1958; Z. Klukowski, Zamojszczyzna, t. 1: 1918-1943, t. 2: 1944-1956, Warszawa 2007. 
Zbiory hr. JERZEGO MoszYŃSKIEGo (1847-1924) publicysty, działacza społecznego, kolekcjonera (100 j.).

Zawierają: fragment archiwum Fryderyka Józefa Moszyńskiego (1738-1817) marszałka wielkiego koronnego), materiały do konfederacji targowickiej, Sejmu Czteroletniego, skarbowości, inwentarze biblioteki Moszyńskich, spuściznę Ignacego Prądzyńskiego (por. spuść.); trzy cenne rękopisy zabytkowe: Kodeks Gracjana z XIII wieku, ilum.; 5 ksiąg Pisma św. ze Starego Testamentu w jęz. hebrajskim, łacińskim i niemieckim skopiowany przez mnicha niemieckiego Arona w XVIII wieku, ilum.; Koran w jęz. arabskim z XIXw., ilum. Przekazane Bibliotece w 1923 roku przez Jerzego Moszyńskiego, publicystę i zbieracza. Bibliograf.: W. Cabaj, Darowizna Jerzego Moszyńskiego dla Biblioteki Katolickiego Uniwersytetu Lubelskiego, ,Teka Komisji Historycznej”, 2 (2005) s. 42-72.

Zbiory JeRzego Wilhelma VON RAUMERA (1800-1856) dyrektora Królewskiego Archiwum w Berlinie, historyka Brandenburgii i Prus (50 j.) Materiały do historii Prus i Brandenburgii od XVI do XIXw. (odpisy dokumentów z archiwum berlińskiego i listów różnych $\mathrm{m}$. in. Metternicha). Otrzymane ze Zbiornicy Księgozbiorów Zabezpieczonych w 1946 roku. Bibliogr.: B. Zezula, Rękopisy Georga Wilhelma von Raumera w Bibliotece Uniwersyteckiej KUL, ABMK, 88 (2007) s. 355-376.

Zbiory STANiSŁaWA SKIBIŃSKIEGo (1919-1980) biologa, konserwatora przyrody, muzealnika, archiwisty, regionalisty, etnografa, badacza przeszłości ziemi chełmskiej - materiały dotyczące przeszłości Ziemi Chełmskiej, w tym materiały źródłowe oryginalne z XVII-XX wieku i współczesne odpisy oraz opracowania Autora (ok. 50 jednostek).Zob. spuścizna Stanisława Skibińskiego.

Zbiory Jana Steckiego (1871-1954) posła do Dumy, ministra spraw wewnętrznych w rządzie Kucharzewskiego (1917-1918), senatora RP. (120 j.). Zawierają materiały do historii społecznej i gospodarczej Lubelszczyzny oraz działalności Steckiego jako posła do Dumy (por. spuść.). Ponadto znajdują się tu materiały gospodarczo-prawne dotyczące majątku Łańcuchów i genealogiczne dotyczące rodziny Suffczyńskich, dawnych właścicieliŁańcuchowa. Zakupione w 1950 roku. Bibliograf.: H. Ziółek, Archiwum Jana Steckiego (katalog rękopisów), ABMK, 57 (1988) s. 331-447.

Zbiory BRONISŁAWA UsSASA (1885-1977) księdza prałata d. diecezji mohylowskiej, członka Komisji Rewindykacyjnej polskiego mienia kulturalnego (86 jednostek). Odpisy i streszczenia dokumentów z archiwów Warszawy, Wilna, Grodna i Petersburga (Leningradu), a także dotyczące Kościoła katolickiego (unickiego) na terenie Królestwa Polskiego, ziem dawnej Rzeczypospolitej oraz całego cesarstwa rosyjskiego od poł. XIX w. do dwudziestych lat XX wieku, m.in. akta parafii św. Katarzyny w Petersburgu, spuścizna ks. Konstantego Budkiewicza (por. spuścizna), fragmenty spuścizn ks. Fryderyka Żarskara, ks. Leonida Fiodorowa (1878-1935) egzarchy kościoła katolickiego w obrządku wschodnio-rosyj- 
skim. Ponadto spuścizna samego Ussasa (por. spuścizna). Przekazane Bibliotece w latach 1964-1977. Bibliogr.: Zbiór rękopisów ofiarowanych przez ks. B. Ussasa Bibl. Uniwersyteckiej KUL, „Archiwa Biblioteki i Muzea Kościelne”, 39 (1979) s. 55-126 [Katalog rękopisów, oprac. H. Mańkowska, s. 63-126].

Zbiory IgNACEgo Wierobieja (1887-1970) księdza dziekana w Kamieńcu Litewskim, po II wojnie światowej proboszcza w Hajnówce, historyka (ok. 45 j.). Materiały historyczne i notaty dotyczące historii archidiakonatu brzeskiego, parafii, kościołów, klasztorów, dóbr kościelnych na terenach b. diecezji pińskiej i łuckiej. Zakupione w 1976 roku.

b) Zbiory miejskie, cechowe i kościelne.

1. Dokumenty miasta Lublina, cechów lubelskich oraz dokumenty dotyczące innych miast i wsi Lubelszczyzny XIV-XVIII wieku. Bibliogr.: Najstarsze dokumenty pergaminowe (XIV-XVII w.) w zbiorach rękopiśmiennych Biblioteki Uniwersyteckiej KUL, ABMK, 95 (2011) s. 157-186; Najstarsze dokumenty pergaminowe (XIV-XVII w.) dotyczace Lublina i Lubelszczyzny w zbiorach rękopiśmiennych Biblioteki Uniwersyteckiej KUL (ok. 25 stron), w: Lublin a książka. Część II. Centrum i peryferie, red. A. Krawczyk, Lublin 2011, s. 15-36; Nowy katalog dokumentów i listów Biblioteki Uniwersyteckiej KUL, oprac. A. Modlińska-Piekarz, Lublin 2012, ss. $170+$ il.

2. Księga cechu piekarskiego w Lublinie z lat 1590-1821. Bibliogr.: J. Kamiński, Z przeszłości rzemiosła piekarskiego w Lublinie, Lublin 1932.

3. Księgi metrykalne kolegiaty św. Michała w Lublinie (księgi urodzonych, ślubów i zmarłych z lat 1636-1797 (kserokopie z mikrofilmów zrobionych w latach siedemdziesiątych XX wieku).

4. Księgi wizytacji i rachunkowe niektórych parafii, min. z Chełma, Szczebrzeszyna.

5. Księgi metrykalne urodzeń, małżeństw i zgonów parafii Żdżanne (oryginał).

6. Księga wójtowska wsi Bukowina (na Zamojszczyźnie) spisana przez wójta Jędrzeja Bulicza, obejmuje lata 1701-1839.

7. Liczne nadania królewskie, wypisy z akt grodzkich, dokumenty notarialne, oraz dokumenty kościelne z terenów całej dawnej Rzeczypospolitej (XV-XVIII wieku).

8. Zbiory Kapituły Greckokatolickiej w Przemyślu (ok.100 jednostek). Rękopisy z Biblioteki Kapituły przekazane wraz z księgozbiorem w 1946 roku stanowią: księgi liturgiczne z XVI-XVIII wieku z cenną pozycją - dziełami mnicha, Maksyma Greka w kodeksie z przełomu XV/XVIw. Bibliogr.: Â. N. Ŝcapov, Vostočnoslavânskie i ûžnoslavânskie rukopisnye knigi v sobraniâch Pol'skoj $\mathrm{Na}$ rodnoj Respubliki, t. 2, s. 7-36; A. Naumow, A. Kaszlej, Rękopisy cerkiewnostowiańskie w Polsce. Katalog, Kraków 2002 [oraz wydanie drugie zmienione 2004]. 
9. Liczne Silesiaca z XVII-XIX wieku, m.in. księgi parafialne kościoła ewangelickiego w Szprotawie odpisy dokumentów z lat 1348-1712, z Koziej Szyi (Capricolla) 1694-1857 i Kożuchowie (Freistadt). Księgi wizytacji parafii ewangelickiej w Leginicy oraz księgi rachunkowe innych parafii ewangelickich na Śląsku.

10. Dokumenty Kolegiaty w Dobrym Mieście XV-XVIII wieku.

c) Archiwa rodzinne (min.)

Archiwum rodziny Czosnowskich - nadania królewskie, dokumenty notarialne, opracowania genealogiczne, odpisy dokumentów, korespondencja.

Archiwum rodziny Suffczyńskich i Steckich (zob. Zbiory Jana Steckiego).

\section{d) Organizacji, Towarzystw, Czasopism}

Armia Krajowa (fragmenty): dokumenty organizacji podziemnych działających na terenie Rzeszowszczyzny, tj. Archiwum AK Podokręgu Rzeszów przekazane przez Edwarda Brydaka i Michała Beresia, dokumenty AK obwodu lubartowskiego przekazane przez Czesława Gregorowicza, dokumenty AK obwodu biłgorajskiego przekazane przez Tadeusza Iwanowskiego, dokumenty AK na Lubelszczyźnie, (min. dokumenty AK obwodu zamojskiego) ze zbiorów Zygmunta Klukowskiego i Konrada Bartoszewskiego oraz Piotra Zwolaka (tu również materiały o Narodowych Siłach Zbrojnych, Wolność i Niezawisłość), dokumenty AK okręgu warszawskiego dokumenty AK okręgu łódzkiego (fragmenty), Obwód VII „Obroża” (archiwum kompletne) przekazane przez ppłka Kazimierza Krzyżaka, mjra Władysława Wrotniaka, mjra Józefa Załogę, mjra Romana Grotowskiego i Jana Gozdawę-Gołębiowskiego; relacje, meldunki, rozkazy, plany konspiracyjne, taktyczne, wspomnienia, relacje, opracowania itd.

Chrześcijański Związek Akademicki YMCA - Fragment zawierający papiery organizacji oraz korespondencję Williama Johna Rose, założyciela YMCA w Polsce.

„Spotkania” (redakcja czasopisma) - fragmenty: materiały redakcyjne, teksty artykułów przygotowywanych do druku, materiały do działaności, korespondencja.

Stowarzyszenie Katolickiej Młodzieży Akademickiej „Iuventus Christana” fragment zawierający materiały źródłowe i wspomnienia dotyczące działalności Towarzystwa z lat 1921-1949.

Stowarzyszenie Katolickiej Młodzieży Akademickiej „Odrodzenie” - fragment archiwum: historia stowarzyszenia autorstwa Konstantego Turowskiego, materiały do działalności, prace członków, korespondencja.

Stowarzyszenie Katolików Polskich w Niemczech „Polonia Semper Fidelis” - protokoły posiedzeń, sprawozdania, materiały do działalności, korespondencja (zob. spuścizna Jana Szpondera).

Stronnictwo Narodowe (fragmenty ze zbiorów Antoniego Dargasa działacza Stronnictwa Narodowego na emigracji - materiały szczątkowe z pobytu w Wielkiej Brytanii z lat 1941-1991, materiały szczątkowe dotyczące Rządu Polskiego w Londynie i Stronnictwa Narodowego na emigracji z lat 1941-1953, materiały 
szczątkowe dotyczące działalności Rady Politycznej na emigracji w latach 19491953, materiały dotyczące zjednoczenia emigracji polskiej z lat 1953-1954, materiały dotyczące niezależnej agencji prasowej Continental News Service, materiały na temat działalności Związku Pomorskiego w Wielkiej Brytanii w latach 19451960 (zob. spuścizna Antoniego Dargasa).

Stronnictwo Pracy - zawiera m.in. materiały źródłowe do działalności Stronnictwa na emigracji, fragment spuścizny Konrada Sieniewicza (zob. spuścizna Konrada Sieniewicza), Karola Popiela (zob. spuścizna Karola Popiela), Stefana Kaczorowskiego iStefana Glasera orazmateriały dotyczące innych organizacji i stowarzyszeń chrześcijańsko-demokratycznych, przeważnie Unii Chrześcijańskiej Demokracji Europy Środkowej (CDUES), i związków tych partii ze Stronnictwem Pracy.

Towarzystwo Filareckie „Eleusis” (działające w okresie międzywojennym) organizacja religijno-patriotyczna - dokumenty organizacyjne, materiały ze zjazdów, protokoły posiedzeń, korespondencja Wincentego Lutosławskiego, założyciela Towarzystwa i innych członków, m.in. Tadeusza Strumiłły. Materiały dotyczące prób reaktywowania działalności Towarzystwa w latach powojennych.

Towarzystwo Filomatów - dokumenty organizacyjne Towarzystwa, listy filomatów m.in. Jana Czeczota, Józefa Jeżowskiego, Stanisława Kozakiewicza, Onufrego Pietraszkiewicza oraz autografy drobnych utworów poetyckich, prac organizacyjnych i listów Adama Mickiewicza (por. spuścizna). Bibliografia: H. Mańkowska, Rękopisy z «Archiwum Filomatów». Fragment inwentarza zbiorów rękopiśmiennych Biblioteki KUL, ABMK, 26 (1973) s. 59-88; H. Mańkowska, Rękopisy z „Archiwum Filomatów”. Katalog, ABMK, 47 (1983) s. 107-174.

Związek Literatów Polskich Oddział w Lublinie - fragmenty: protokoły posiedzeń, opinie, wnioski, sprawozdania z działalności, wspomnienia, fotografie, korespondencja, (materiały Matyldy Wełny, wiceprezesa, sekretarza i członka ZLP).

Kserokopie: archiwum generała Władysława Andersa zdeponowane w Instytucie Hoovera w Stanford (kserokopie materiałów archiwanych zgromadzone przez Leona Antoniego Sułka) raporty na temat ziem wschodnich Polski pod okupacją sowiecką, sytuacji kościoła na ziemiach wschodnich pod okupacją sowiecką, przymusowych poborów Polaków do Armii Czerwonej; NKWD - dokumentacja na temat obozów jenieckich NKWD w Kozielsku, Starobielsku i Ostaszkowie uzyskana od władz radzieckich 13 kwietnia 1990 roku, przekazana przez ks. Grzegorza Kalwarczyka.

e) Spuścizny poszczególnych osób w układzie alfabetycznym:

ACHREMOWICZOWA WANDA (1901-1974) nauczycielka, metodyk nauczania, historyk literatury polskiej, autorka słuchowisk dla dzieci. Prace naukowe i literackie, audycje radiowe, inscenizacje i bajki dla dzieci, materiały do działalności, notaty, korespondencja, listy.

AraszKIEwICZ Feliks (1895-1966) historyk literatury. Prace naukowe, notaty, korespondencja, listy. 
ARChita JAN (1912-1969) publicysta, działacz katolicki. Materiały do działalności, artykuły, przekłady.

BAGIEŃSKA IRENA (1897-1971) działaczka oświatowa. Dokumenty osobiste, materiały do działalności, notaty.

BARTOSzewsKi KonRAD (1914-1987) porucznik AK. Dokumenty osobiste, wspomnienia, materiały operacyjne AK na Lubelszczyźnie, relacje, korespondencja.

BĄK WOJCIECH (1907-1961) poeta. Utwory literackie i publicystyczne.

BERKAN KAZIMIERA (1889-1969) świecka działaczka misyjna okresu międzywojennego. Wspomnienia rodzinne i osobiste. córki.

BERKAN WŁADYSŁAw (1859-1941) działacz emigracyjny. Biografia autorstwa

BiąKowski Leon (1885-1952) historyk, dyrektor Woj. Arch. Państw, w Lublinie. Materiały autobiograficzne, prace naukowe, materiały warsztatowe, źródła historyczne z XV- XIX wieku.

BIEŃKOWSKI LUDOMIR (1925-1987) historyk. dokumenty osobiste, notaty, prace naukowe, materiały do działalności naukowo-pedagogicznej, materiały źródłowe i wypisy, wykłady, korespondencja, listy.

BOROWY WACŁAW (1890-1950) historyk literatury, krytyk literacki. Notaty.

BRAUN JERZY (1901-1975) poeta, powieściopisarz, filozof, działacz społeczny i polityczny. Utwory literackie i publicystyczne, materiały dotyczące działalności w Związku Literatów Polskich i Klubie Inteligencji Katolickiej w Warszawie, korespondencja, listy.

BRYDAK EDWARD (1901-1978) żołnierz AK Podokręgu Rzeszów. Dokumenty osobiste, materiały do działalności konspiracyjnej, wspomnienia, archiwum AK Podokręgu Rzeszów, korespondencja, listy zob. archiwa organizacji: Armia Krajowa.

Budkiewicz Konstanty (XIX/XXw.) proboszcz w parafii św. Katarzyny w Petersburgu. Materiały do działalności, rozprawy, notaty, listy.

ChWAlewiK Witold (1900-1985) historyk literatury, tłumacz z j. angielskiego. Dokumenty osobiste, prace naukowe, przekłady z języka angielskiego, materiały do działalności, utwory literackie, korespondencja, listy.

Csorba Tibor (1906-1985) językoznawca, malarz, tłumacz, historyk literatury. Dokumenty osobiste, prace naukowe i publicystyczne, notaty, materiały do działalności naukowej i społecznej, korespondencja, listy.

CYWIŃSKI STANISŁAW (1887-1941) historyk literatury polskiej, członek Eleusis, publicysta. Pamiętniki, artykuły naukowe i publicystyczne, materiały do działalności, korespondencja, listy.

CZAPSKI JózeF (1896-1993) malarz, prozaik. Kserokopia dzienników z lat 1942-1991.

CzArkowski LudwiK (1855-1928) bibliotekarz, językoznawca. Materiały, korespondencja.

Dargas Antoni (1915-1991) działacz Stronnictwa Narodowego na emigracji. Dokumenty osobiste, materiały do działalności politycznej i społecznej, korespondencja (zob. zbiory Antoniego Dargasa). 
DĄBrowski Eugeniusz (1901-1970) ksiądz, teolog biblista. Fragment spuścizny: dokumenty osobiste, prace naukowe, materiały do działalności, korespondencja, listy.

Gaberle Eustachy (1891-1947) bibliotekarz Biblioteki Uniwersytetu Jana Kazimierza we Lwowie i Dyrektor Biblioteki Uniwersyteckiej we Wrocławiu. Dokumenty dotyczące biblioteki Uniwersyteckiej we Lwowie, korespondencja.

GoŁUBIEW ANTONI (1907-1979) pisarz, publicysta katolicki, historyk. Utwory literackie, artykuły publicystyczne, wspomnienia, materiały różne, m.in. warsztatowe.

Gregorowicz CzesŁaw. Materiały dotyczące AK obwodu lubartowskiego, korespondencja.

GUSTAw ROMUALD OFM (1911-1976) bernardyn, dyrektor Biblioteki Uniwersyteckiej KUL w latach 1950-1976. Dokumenty osobiste, prace naukowe, notaty, materiały warsztatowe, materiały na temat Biblioteki KUL, korespondencja, listy.

HaBURA FranciszeK (1843-1921) powstaniec styczniowy, pedagog, literat, thumacz z języka łacińskiego. Dokumenty osobiste, notaty studenckie z wykładów, przekłady z języka łacińskiego, prace naukowe.

HAHN WIKTOR (1871-1959) historyk literatury. Notaty, materiały do działalności, korespondencja, listy.

Halban LeON (1893-1960) historyk prawa. Dokumenty osobiste, materiały biograficzne, materiały do działalności, fotografie rodzinne, korespondencja, listy.

Heintsch Paweł (1924-2008) ksiądz, poeta, pisarz, publicysta. Dokumenty osobiste, utwory literackie, naukowe i publicystyczne, przemówienia, korespondencja, listy (w zbiorach Matyldy Wełny).

HoRDEJUK RYsZARD (1944-1991) historyk, bibliotekarz, współpracownik Archiwum Wschodniego. Dokumenty osobiste, materiały dot. Archiwum Wschodniego w latach 1983-1989, materiały dot. AK, relacje żołnierzy.

IlŁAKOWICZÓWNA KAZIMIERA (1892-1983) poetka. Utwory literackie, listy.

IwANOWSKI TADEUSZ (1916- ) regionalista powiatu biłgorajskiego. Dokumenty osobiste, materiały do działalności turystyczno-krajoznawczej i harcerskiej, materiały na temat $\mathrm{AK} \mathrm{w}$ powiecie biłgorajskim, opracowania.

JAKUBANIS HENRYK Roman (1879-1949) historyk filozofii. Dokumenty osobiste, notaty, prace naukowe, wykłady, materiały do działalności, korespondencja, listy.

JASTRZĘBSKI ZDZISŁAW (1930-1972) historyk literatury. Dokumenty osobiste, prace naukowe, notatki, materiały warsztatowe, korespondencja.

KAMIŃSKI JAN (1892-1970) historyk prawa. Prace naukowe, materiały do działaności, odpisy dokumentów dotyczących cechów lubelskich sporządzone z oryginałów, korespondencja.

KAPUŚCiŃSKI JÓZEF (1904-1968) lubelski poeta ludowy. Pamiętniki, utwory literackie, korespondencja.

KaWyn StEFAn (1904-1968) historyk literatury. Prace naukowe, materiały do działalności, korespondencja, listy.

KLEINER JuLIUSz (1886-1957) historyk literatury. Materiały biograficzne, prace naukowe, korespondencja, listy. 
KLuKowski Zygmunt (1885-1959) doktor nauk medycznych, lekarz, bibliofil, historyk, działacz społeczny. Materiały autobiograficzne, prace naukowe, materiały źródłowe, m.in. fragmenty akt oddziałów partyzanckich AK na Zamojszczyźnie, korespondencja, listy (zob. zbiory Z. Klukowskiego).

KŁosowski Józef Nikodem (1904-1959) poeta, pisarz, publicysta. Materiały biograficzne, listy do żony Zofii z lat 1942-1944, literatura publicystyczna, naukowa i literacka na temat pisarza autorstwa Matyldy Wełny i przez nią zgromadzona (zob. spuścizna Wełna Matylda).

KorCiK ANTONi (1892-1969) ksiądz, logik, filozof, historyk logiki. Prace naukowe, materiały do działalności, materiały warsztatowe, notaty, korespondencja.

KosiŃSKI JAN (1915-1994) więzień niemieckich obozów koncentracyjnych, działacz na rzecz rozpowszechniania wiedzy o niemieckich obozach koncentracyjnych. Dokumenty osobiste, prace naukowe i publicystyczne, materiały obozowe, materiały do działaności, korespondencja, listy.

Kossowski Aleksander (1886-1956) historyk. Dokumenty osobiste prace naukowe, materiały do działalności i warsztatowe, notaki, korespondencja, listy.

Kот Stanistaw (1885-1975) historyk kultury i wychowania, działacz polityczny. Dokumenty osobiste, prace naukowe i dydaktyczne, materiały do działalności, korespondencja, listy.

KozŁowsKa JADWIGA (1906-1993) żołnierz AK, działaczka społeczna na rzecz pomocy kombatantom i ochrony pamięci walk i męczeństwa. Dokumenty osobiste, materiały na temat ZWZ AK okręgu sieradzkiego, korespondencja, listy.

KUKULSKI ZYGMUNT (1890-1944) pedagog, historyk. Dokumenty osobiste, prace naukowe i dydaktyczne, notaty, materiały do działalności, korespondencja, listy.

KunOwSKa MARIa (1914-2005) bibliotekarka. Dokumenty osobiste, materiały do działalności, materiały na temat Biblioteki KUL, materiały na temat Wojskowej Służby Kobiet okręgu Lublin oraz Związku Harcerstwa Polskiego.

KunOwSKi STEFAn (1909-1977) pedagog, teoretyk pedagogiczny. Dokumenty osobiste, prace naukowe i dydaktyczne, materiały do działalności, korespondencja, listy.

KRZACZeK STEFAn żołnierz AK. Dokumenty obwodu zamojskiego AK.

LIEBERT JeRZY (1904-1931) poeta. Dokumenty osobiste, utwory literackie, korespondencja.

LAWRYNowicZ Zygmunt (1925-1987) poeta, pisarz. Dokumenty osobiste, dzienniki z lat 1949-1987, utwory literackie i publicystyczne (np. eseje, artykuły polemiczne, pogadanki w Radio Wolna Europa), tłumaczenia z języków włoskiego $i$ angielskiego, materiały do działalności, materiały na temat Andrzeja Seweryna Kopczyńskiego (1927-1954), alpinisty od 1946 przebywającego na emigracji, korespondencja, listy.

Łoś Jan Stanisław (1890-1974) historyk. Dokumenty osobiste, prace naukowe i dydaktyczne, przekłady z języka łacińskiego, materiały do działalności, materiały warsztatowe, korespondencja, listy.

ŁUBIEŃSKA-STARZEWSKA ElŻBIETA pedagog. Zbiory dotyczące prywatnego gimnazjum Żeńskiego im. św. Tereski w Rabce 
Majkowski Edmund (1892-1951) ksiądz, historyk, bibliotekarz, archiwista, numizmatyk. Dokumenty osobiste, prace naukowe, materiały warsztatowe, korespondencja.

Mickiewicz AdAm (1798-1855) poeta. Utwory literackie, listy. Bibliogr.: zob. wyżej - Towarzystwo Filomatów.

MiŁKowSKi StanisŁaW (1881-1961) ksiądz. Dzienniki, rozważania konferencyjne.

MosZYŃSKI FRYDERYK (1738-1817) marszałek wielki koronny w latach 17931795. Dokumenty urzędowe (m.in. skarbowe, polityczne). Zob. zbiory hr. Jerzego Moszyńskiego.

NowaK-DŁużEwski Juliusz (1893-1972) historyk literatury. Dokumenty osobiste, prace naukowe i dydaktyczne, materiały do działalności, korespondencja, listy.

NowodworsKi WiTOLD (1907-1978) historyk filozofii, logik, bibliotekarz. Dokumenty osobiste, prace naukowe i dydaktyczne, materiały do działalności, notaty, korespondencja, listy.

OczKowski StanisŁaw bibliofil, badacz heraldyki i genealogii. Wypisy i opracowania heraldyczne i genealogiczne.

OstrowsKa Eda (1959- ) poetka. Dokumenty osobiste, prace literackie, recenzje publikacji, materiały do działalności, korespondencja.

PastuszKa Józef (1897-1989) ksiądz, teolog, filozof, psycholog. Prace naukowe i dydaktyczne, korespondencja.

Petrani Aleksy (1900-1977) ksiądz, historyk prawa kanonicznego, kapelan AK. Prace naukowe i dydaktyczne, materiały źródłowe do historii Kościoła, korespondencja, listy.

PęCHERSKI CeZARY (1881-1925) ksiądz, historyk literatury. Notaty, materiały warsztatowe, fragmenty prac naukowych, notaty z wykładów z lat studenckich.

Pollakówna Marzena (1926-1971) historyk. Dokumenty osobiste, prace naukowe, materiały do działalności, notaty, korespondencja.

Pomian KRZYSzTof (1934- ) filozof, historyk, eseista, archiwista. Dokumenty osobiste, prace naukowe i publicystyczne, artykuły, eseje, korespondencja, listy.

Popiel Karol (1887-1977) senator RP, przywódca Narodowej Partii Robotniczej, wiceminister i minister w Rządzie RP na emigracji w czasie II wojny światowej, prezes Stronnictwa Pracy. Dokumenty osobiste, wspomnienia z działalności politycznej z lat 1922-1968, wspomnienia z dzieciństwa, drobne prace, materiały do działalności, korespondencja.

PopŁaWSKi MieczYSŁaw (1893-1946) filolog klasyczny. Dokumenty osobiste, prace naukowe, przekłady z języka łacińskiego, materiały do działalności, notaty, korespondencja, listy.

PŁodzień StanisŁaw (1913-1962) ksiądz, historyk prawa kanonicznego. Prace naukowe, materiały do działalności, korespondencja.

PRĄDZYŃSKI IGNACY (1792-1850) generał. Pamiętniki, materiały do działalności (korespondencja sztabu Kwatermistrzostwa w czasie powstania listopadowego), prace strategiczne. W jej skład wchodzą rękopisy najważniejszych dzieł gen. P. takich jak: Pamiętniki, drobne pisma, memoriały wojskowe, recenzje, materiały 
dotyczące ostatnich kampanii napoleońskich, a także Akta Kwatermistrzostwa Generalnego z 1831 roku. Bibliografia: W. Cabaj, Darowizna Jerzego Moszyńskiego dla Biblioteki Katolickiego Uniwersytetu Lubelskiego, ,Teka Komisji Historycznej. Polska Akademia Nauk. Oddział w Lublinie", 2 (2005) s. 42-72.

PRzELASKOwsKi RYSZARD (1903-1971) historyk, archiwista, bibliotekarz. Dokumenty osobiste, wspomnienia, notaty, korespondencja.

PTASzYcki StAnisŁaw (1854-1933) historyk literatury, pierwszy dziekan Wydziału Humanistycznego KUL. Materiały warsztatowe (notaty z archiwów Petersburga), korespondencja.

RADZISZEWSKI IDZI (1871-1922) ksiądz, rektor Akademii Duchownej w Petersburgu, założyciel i pierwszy rektor KUL. Dokumenty osobiste, materiały do działalności (jako rektora Akademii Duchownej w Petersburgu i organizatora KUL), prace naukowe, notaty, korespondencja.

Raumer Georg Wilhelm von (1800-1856), historyk, dyrektor Tajnego Archiwum Państwowego w Berlinie, radca stanu. Dokumenty, osobiste, dzienniki, notaty, materiały źródłowe oryginalne oraz kopie i odpisy dokumentów XIV-XIX wieku korespondencja. Bibliografia: B. Zezula, Rękopisy Georga Wilhelma von Raumera w Bib-liotece Uniwersyteckiej KUL, „Archiwa, Biblioteki i Muzea Kościelne", 88 (2007) s. 355-376.

Riabinin SERgiusz (1918-1997) poeta, działacz ochrony przyrody, biolog. Prace literackie i publicystyczne, korespondencja.

RzEUSKa MARIa (1908-1982) - historyk literatury. Dokumenty osobiste, prace naukowe, materiały warsztatowe, notaty, korespondencja.

Sieniewicz KonRad (1912-1996) działacz Stronnictwa Pracy, sekretarz generalny Unii Chrześcijańskiej Demokracji Europy Środkowej (CDUES), reprezentant CDUES w ONZ. Dokumenty osobiste, przemówienia, artykuły, luźne notaty, wspomnienia, opis I Pielgrzymki Jana Pawła II do Polski, charakterystyka Chrześcijańskiej Demokracji obejmująca historię partii, jej przywódców i działalność konspiracyjną i emigracyjną z poprawkami i dopiskami K. Popiela, korespondencja, listy.

SKĄPSKI FrANCISZEK (1881-1966) inż., działacz niepodległościowy, tłumacz z j. niem. dzieł Józefa Schneiderfrankena czyli Bo Yin Ra (1876-1943). Dokumenty osobiste, materiały do działalności, prace przekładowe, korespondencja.

SkIBIŃSKi StAniSŁAw (1919-1980), regionalista, badacz Ziemi Chełmskiej, archiwista, kustosz muzeum w Chełmie. Dokumenty osobiste, prace naukowe i popularnonaukowe, notaty, opracowania, materiały do działalności, korespondencja, listy (zob. zbiory Stanisława Skibińskiego)..

SŁomkowski AnTONi (1900-1982) ksiądz, teolog, rektor KUL. Wspomnienia.

SŁuŻEwski CZESŁaw historyk, regionalista. Dokumenty obwodu zamojskiego AK.

SmolKa FranciszeK (1810-1899) działacz polityczny w Galicji. Materiały do działalności, korespondencja.

Smolka StanisŁaw (1854-1924) historyk. Dokumenty osobiste, prace naukowe, notaty, materiały do działalności, korespondencja. 
SokoŁowski CzesŁaw (1877-1952) bp, rektor KUL w latach 1924-1925. Dokumenty osobiste, dzienniki, prace naukowe, notaty, materiały do działalności, korespondencja, listy.

STECKI JAN (1871-1954) poseł do Dumy, minister spraw wewnętrznych w rządzie Jana Kucharzewskiego, senator RP. Dokumenty osobiste, materiały do działalności, archiwum rodzinne, korespondencja, listy. Bibliogr.: zob. wyżej-Zbiory Jana Steckiego.

STEPHEN BERnARD historyk literatury. Prace naukowe, materiały warsztatowe, korespondencja.

StRumileo TADEuSz (1884-1958) filozof, pedagog, instruktor harcerski, harcmistrz. Materiały do Stowarzyszenia Eleusis, notaty, korespondencja, listy.

StRZESZEwSKI CZESŁaw (1903-1999) socjolog, twórca i badacz katolickiej nauki społecznej, działacz katolicki. Prace naukowe, notaty, korespondencja.

SUŁowsKi ZyGMUNT (1920-1995) historyk. Dokumenty osobiste, prace naukowe i dydaktyczne, materiały do działalności, materiały warsztatowe, korespondencja.

Swieżawski Stefan (1907-2004) historyk filozofii. Wspomnienia, prace naukowe, materiały do działalności, notaty, korespondencja.

SYKULSKI JózEF (1905-1994) pedagog, literat, krajoznawca. Dokumenty osobiste, prace naukowe i literackie, publicystyka, pamiętniki, wspomnienia, notaty, materiały do działalności, korespondencja, listy.

SzANIAWSKI JeRZY (1886-1970) dramaturg, felietonista, pisarz. Prace literackie. Bibliografia: Jerzy Szaniawski, Dramaty zebrane, t. 1-2, Kraków 1958.

Szeliga-SzEligowsKa EmiLia (1878-1954) pierwsza pracownica i organizatorka Biblioteki KUL, dokumenty osobiste, materiały dotyczącze KUL i Biblioteki Uniwersyteckiej, korespondencja.

SZPONDER JAN ANDRZEJ (1920-1990) dr inż. górnictwa, żołnierz AK, emigrant, działacz Stronnictwa Narodowego, współpracownik Antoniego Dargasa, prezes Stowarzyszenia Katolików Polskich w Niemczech „Polonia Semper Fidelis”. Materiały osobiste z lat 1930-1990 rozprawy, artykuły, przemówienia, notaty, korespondencja, listy oraz bardzo licznie zgromadzone materiały dotyczące Stowarzyszenia Katolików Polskich w Niemczech „Polonia Semper Fidelis” z lat 19781990 - są to sprawozdania, protokoły, oświadczenia, korespondencja komunikaty uwagi, materiały do działalności jako prezesa Stowarzyszenia Polonia Semper Fidelis oraz z działalności w „Associatio Sanctus Benedictus Patronus Europae” z lat 1982-1988, materiały dotyczące Stronnictwa Narodowego. Spuścizna zawiera bogaty materiał fotograficzny, są także zapisy dźwiękowe i wideo.

SZYMAŃSKi Antoni (1881-1942) ksiądz, filozof, socjolog, rektor KUL. Dzienniki.

TATARKIEWICZ WŁadysŁaW (1886-1980) historyk filozofii, etyk, estetyk, historyk sztuki. Dokumenty osobiste, prace naukowe, materiały do działalności, notaty, wykłady uniwersyteckie, korespondencja, listy.

Terlaga Jan (1894-1972) ksiądz, teolog biblista, historyk kościoła. Materiały do działalności, prace naukowe, korespondencja. 
Turowski Konstanty (1907-1983) działacz Stowarzyszenia Katolickiej Młodzieży Akademickiej „Odrodzenie”, członek Chrześcijańskich Związków Zawodowych, Stronnictwa Pracy. Dokumenty osobiste, wspomnienia, prace naukowe i publicystyczne, materiały do działalności, korespondencja.

Turkowski TAdeusz (1883-1957) nauczyciel, działacz społeczny i oświatowy, bibliotekarz i historyk książki. Artykuły, odczyty, materiały na temat Wyższej Szkoły Rzemieśniczej w Łodzi oraz Szkoły Rolniczej dla Młodzieży Wiejskiej w Pszczelinie i Seminarium Nauczycielskiego w Białymstoku, zbiór wycinków prasowych (dotyczących Kresów z lat 1870-1957), materiały różne do działalności, korespondencja. Bibliografia: B. Zezula, Archiwum i biblioteka Tadeusza Turkowskiego i jego rodziny źródłem do badań działalności oświatowo kulturalnej wśród społeczeństwa polskiego na początku XX wieku, w: Książka ponad podziałami. Materiały z ogólnopolskiej konferencji naukowej, Lublin 16-18 listopada 2004, red. A. Krawczyk, Lublin 2007, s. 277-294; B. Zezula, Sprawy polskie z perspektywy Krakowa i Paryża. Korespondencja Tadeusza Turkowskiego z Zygmuntem Lubicz-Zaleskim w zbiorach rękopiśmiennych Biblioteki KUL, w: Lublin a książk. Część II. Centrum i peryferie, red. A. Krawczyk, Lublin 2011, s. 5982.

TworkowsKi StanisŁaw (1901-1999) kapelan wojskowy AK, pisarz, działacz endecki. Materiały na temat katolickiego duchowieństwa wojskowego.

TYBOROwski LudwIK historyk literatury. Prace naukowe, publicystyczne i literackie.

UsSAs BronisŁaw (1885-1977) ksiądz, prałat d. diecezji mohylowskiej, członek Komisji Rewindykacyjnej polskiego mienia kulturalnego. Wspomnienia, materiały do działalności, notaty, korespondencja. Bibliogr.: por. wyżej - zbiory B. Ussasa.

WAŁĘSA LECH (1943- ) działacz Solidarności, prezydent RP. Dokumenty osobiste (dyplomy, odznaczenia, medale), albumy otrzymane w darze, materiały dotyczące Solidarności, korespondencja.

WeŁna Matylda (1925-2000), pisarka, poetka, publicystka. Dokumenty osobiste, dzienniki, wspomnienia, powieści, eseje, wiersze, materiały warsztatowe, korespondencja, listy.

WiERoBIEJ IgNacy (1887-1970) historyk. Zbiory historyczne z XV-XVII wieku, notatki z rękopisów, opracowania, zob. zbiory I. Wierobieja).

WoJcIEchowsKi STEFAn (1899-1980) bibliotekarz, historyk. Dokumenty osobiste, prace naukowe, materiały do działalności, notaty, materiały warsztatowe, korespondencja, listy.

WoJTKOWSKi ANDRzes (1891-1975) historyk, bibliotekarz. Prace naukowe, materiały do działalności, notaty, korespondencja, listy.

WolfF Jerzy (1902-1985), artysta malarz i pisarz. Dokumenty osobiste, wspomnienia, rozważania teologiczno-filozoficzne, materiały różne.

Woronicz Jan PaweŁ (1757-1829) prymas Królestwa Polskiego, arcybiskup metropolita warszawski. Kazania, mowy i pisma. Bibliografia: J. P. Woronicz, Pisma, t. 1-6, Kraków 1832; J. P. Woronicz, Poezje, t. 1-2, Kraków 1832; J. P. 
Woronicz, Kazania, nauki parafialne tudzież homilie i odezwy, Kraków 1857; J. P. Woronicz, Mowy pogrzebowe i homilie, Kraków 1861.

WysZYŃSKi STEFAn (1901-1981) arcybiskup metropolita warszawski, gnieźnieński, prymas Polski, kardynał. Przemówienia, kazania, homilie, korespondencja, listy.

ZAWIEJSKI JERZY (1902-1969) aktor, prozaik, eseista, dramatopisarz. Prace literackie, notaty, korespondencja.

ZaWODZINSKI KAROL WiKTOR (1890-1949) historyk literatury, krytyk literacki. Prace naukowe, listy.

Zwolakiewicz Henryk (1903-1984), malarz grafik, etnograf bibliofil. Dokumenty osobiste, prace naukowe, materiały warsztatowe.

ZGoRZELSKI CZESŁAW (1908-1996) historyk literatury. Dokumenty osobiste, prace naukowe, materiały do działalności, recenzje prac, notaty, materiały warsztatowe, korespondencja, listy.

ŻYWCZYŃSKI MIECZYSŁAW (1901-1978) ksiądz, historyk. Prace naukowe, korespondencja, listy.

Poza omówionymi według powyższego schematu rękopisami wymienić trzeba:

1. Kodeks Gracjana tj. iluminowany rękopis z Concordia discordantium canonum z XIV wieku ofiarowany Bibliotece przez Jerzego Moszyńskiego $25 \mathrm{~V}$ 1923 roku. Bibiogr.: A. Vetulani: Les manuscrits du Decret de Gratian et des oeuvres decretistes dans les bibliothčques polonaises. Studia Gratiana, vol. 1, Bologna 1953; M1.; A. Adamczuk, Prawo i obraz w miniatorstwie średniowiecznym. Iluminowany rękopis Concordia discordantium canonum Gracjana w zbiorach Biblioteki Uniwersyteckiej KUL, Lublin 2009.

2. Kodeks z 1386 r. (papierowy) komentarz do Pieśni nad Pieśniami przypisywany Mikołajowi de Gorran.

3. Kodeks z 1435 roku (papierowy) zawierający egzorcyzmy i Mała Postylle Macieja z Legnicy Postylla Parva.

4. Kodeks pergaminowy (welin) z XV wieku Breviarium Romanum z 1466 roku; iluminowany, z bogato zdobionymi inicjałami.

5. Kodeks pergaminowy (welin) z XV wieku Pismo Święte Starego i Nowego Testamentu. Bibliogr:: A. Zaremba, Rękopis Biblii z Biblioteki Katolickiego Uniwersytetu Lubelskiego. Analiza kodykologiczna. Praca magisterska napisana pod kierunkiem B. Frelińskiej, Lublin 1991, BU KUL, sygn. rkps. 2403A.

6. Kodeks pergaminowy (welin) z XV wieku. Zawiera dzieła św. Augustyna, Bonawentury i Bernarda oraz traktat Seneki o cnotach

7. Kodeks pergaminowy z XV wieku Officia varia.

8. Johannes de Platea, (kodeks papierowy, język łaciński, in folio) super institutionibus Komentarz do Kodeksu Justyniana, pierwsza karta zawiera iluminację.

9. Kodeks pergaminowy (welin) z XIV-XV wieku Sachenspiegel czyli zwierciadto saskie - średniowieczny kodeks prawniczy

10. Statuty synodalne biskupa poznańskiego Andrzeja Laskarego: Statuta synodalia reverendissimi in Christo patris et domini Andreae Lascari, episcopi poznaniensis, BU KUL, rkps, sygn. 109 A. Rękopis posiada własnoręczny podpis 
Jerzego Szembeka na k. 1 recto. Bibliogr.: Statuta synodalia reverendissimi in Christo patris et domini Andreae Lascari, episcopi poznaniensis, w: Starodawne Prawa Polskiego Pomniki, t. 5 Suplementum, Kraków 1877 (uwzględniony jako S II), s. I-XL; J. Sawicki, Synody diecezji poznańskiej i ich statuty, w: Concilia Poloniae, t. 7, Poznań 1952, s. 7-38; H. Mańkowska, Sekcja Rękopisów, ABMK, 23 (1971) s. 145 [129];

11. Kodeks Jerzego Szembeka z Poręby (papierowy z końca XV wieku) kopiariusz listów i mów Eneasza Sylwiusza Piccolominiego z lat 1443-1455. Bibliografia: Codex epistolaris saeculi decimi quinti, ed. A. Sokołowski et J. Szujski, t. 1, w: Monumenta Medii Aevi Historica Res Gestas Poloniae Illustrantia, t. 2, Kraków 1876, s. 320, wzmianka o kodeksie Szembeka w Monumenta Medii Aevi Historica Res Gestas Poloniae Illustrantia, t. 2, Kraków 1876, s. LXII oraz I. Zarębski, Stosunki Eneasza Sylwiusza z Polska i Polakami, Kraków 1939, s. 1315, 67; A. Modlińska-Piekarz, Piętnastowieczny kodeks rękopiśmienny z listami i mowami Eneasza Sylwiusza Piccolominiego w zbiorach Biblioteki Uniwersyteckiej KUL, ABMK, 81 (2004) s. 169-197.

12. Układ systematyczny prawa polskiego z 1554 r. Jana Sierakowskiego, Tytuł rękopisu z Biblioteki hr. Jerzego Szembeka: Statutorum Regni Poloniae Compendium. Bibliografia: Michał Bobrzyński, O nieznanym układzie prawa polskiego przez Jana Sierakowskiego z r. 1554, ,Rozprawy Wydziału Historyczno-Filozoficznego AU", 6 (1877); Jana Sierakowskiego układ systematyczny prawa polskiego z r. 1554, ed. B. Ulanowski i S. Kutrzeba, w: Archiwum Komisji Prawniczej, t. 6, Kraków 1897-1926, s. 99-234. Obecnie powszechnie uważa się go za zaginiony.

13. Sylwa z XVII wieku o tematyce literacko-historycznej zawiera kopie listów królów, dostojników państwowych oraz ludzi biorących udział w życiu politycznym w czasie panowania Wazów. Ponadto zawiera przemówienia polityczne, relacje, mowy obrzędowe i okolicznościowe, twórczość poetycką taka jak panegiryki, epitafia, lamentacje, epigramaty, utwory o charakterze politycznym i dworskim pisane w języku łacińskim i polskim. Bibliogr.: A. Modlińska-Piekarz, Siedemnastowieczna sylwa w zbiorach Biblioteki Uniwersyteckiej KUL, ABMK, 89 (2009) s. 275-314. Ponadto kilka innych sylw z XVII-XVIII wieku.

14. Kopiariusz ostrogski zawierający kopie dokumentów z lat 1753-1758 - listy, relacje, manifesty, dekrety i ordynanse dotyczące podziału Ordynacji Ostrogskiej przez księcia Janusza Sanguszkę.

15. Buckisch und Löwenfels Gottfried Fernand, Schlesischen Religions-Akten [niemiecki kodeks rękopiśmienny, papierowy z XVII wieku (brak tomów 2 i 3)], t. 1: Schlesischen Religions-Akten (Historia Kościoła na Śląsku z lat 1517-1607), t. 4: Ius et Innocenta male reformatarum civitatum Ducati Svidnicensis et Javorensis (z lat 1556-1638).

16. a) Koran rękopiśmienny z XIX w. w skórzanej oprawie kopertowej.

16. b) Koran rękpiśmienny z XIX w. z miniaturką $(24 \times 17 \mathrm{~mm})$.Bibliogr:: Nihad Jord, Koran rękopiśmienny w Polsce, Lublin 1994, (Koran miniaturowy nie został uwzględniony), mps w BU KUL, sygn. rkps 2351. 
17. Akta sądowe miasta Czemierniki. Ziemia Lubelska 1638-1695. Bibliogr.: W. Bielak, Odnaleziona sidemnastowieczna księga akt Sadu Grodzkiego w Czemiernikach (Ziemia Lubelska), ABMK, 75 (2001) s. 459-462.

\title{
THE GUIDE TO THE MANUSCRIPT COLLECTION OF THE LIBRARY OF THE CATHOLIC UNIVERSITY OF LUBLIN
}

\begin{abstract}
Summary
This paper presents the complete manuscript collection of the Library of the Catholic University of Lublin. It shows the number of manuscripts, the time and place of using the collections as well as the inventories and catalogues of the manuscripts both handwritten, in a typescript form and printed. It also includes the published studies concerning the Manuscript Section of the University Library. Next, the work discusses the history of the manuscript collection of the University Library since the creation of the library in 1918 to the present. It presents the characteristics of the mentioned manuscripts, including larger collections (the collections listed here are the ones of Zygmunt Klukowski's, Count Jerzy Moszyński's, Wilhelm von Raumer's, Stanisław Skibiński's, Jan Stecki's, the Rev. Bronisław Ussas's and the Rev. Ignacy Wierobiej's), municipal archive materials (mainly royal documents of the city of Lublin, some guild documents, numerous and various ecclesiastical documents, family archive documents (including the Suffczyńskis, the Steckis, the Czosnowskis), the archives of institutions and magazine publishers (including archive materials of different districts of the Home Army and other underground organizations, some political parties, for example the Labour Party, National Party), the archives of associations and societies (mainly the archive of Philomath Society containing Adam Mickiewicz's autographs) and the legacy of those listed in alphabetical order, as well as other manuscripts, especially the ones of historical value. The data are supplemented with the bibliography for each collection.
\end{abstract}

Translated by Aneta Kiper 